\title{
Clinical Characteristics of Hepatitis in Pregnancy in Pregnant Women with Chronic Hepatitis B Virus Infection and Evaluation of the Efficacy of Antiviral Therpy
}

\author{
CUICUI LI AND XIAOLI BI ${ }^{1 *}$
}

Infection Group of Respiratory Medicine, ${ }^{1}$ Obstetrics and Gynecology Department, The $80^{\text {th }}$ Group Army Hospital of the Chinese People's Liberation Army, Weifang 261021, Shandong, China

Li et al.: Efficacy of Antiviral Therapy in Pregnant Women with Chronic Hepatitis B Virus Infection

To explore the clinical characteristics of hepatitis in pregnant women with chronic hepatitis $B$ virus infection and the efficacy of telbivudine treatment is the main objective. In this study, 136 pregnant women with hepatitis B virus infection diagnosed in our hospital from March 2017 to December 2018 were selected as the research objects. According to whether the patients had hepatitis episodes, they were divided into 96 cases in the seizure group and 40 cases in the non-seizure group. The two groups of patients were compared. The difference of serum alanine aminotransferase, aspartate aminotransferase, hepatitis B virus-deoxyribonucleic acid load, hepatitis B surface antigen, hepatitis B e antigen; randomize the attack group of patients and divide into telbivudine group and entecavir group with 48 cases each. Compare hepatitis B virus-deoxyribonucleic acid load, hepatitis B surface antigen, hepatitis B e antigen, serum alanine aminotransferase, aspartate aminotransferase changes at different times before and after treatment and peripheral blood $T$ helper cell factors and regulatory $T$ cells/T helper 17 cells levels changes and shows differences in neonatal outcomes. The hepatitis B virus-deoxyribonucleic acid load, hepatitis $B$ surface antigen, hepatitis $B$ e antigen, serum alanine aminotransferase and aspartate aminotransferase levels of the hepatitis attack group were higher than those of the non-seizure group and the difference was statistically significant $(\mathbf{p}<\mathbf{0 . 0 5})$. The age of the patients in the hepatitis attack group was mainly concentrated in the range of 22-28 y (56.25\%), onset time is mainly concentrated in $13-24 \mathrm{w}(87.50 \%)$, hepatitis $B$ virus-deoxyribonucleic acid level is mainly $\geq 6 \log 10 \mathrm{IU} / \mathrm{ml}(\mathbf{7 8 . 1 3} \%)$, hepatitis $B$ surface antigen $\geq 4 \log 10 \mathrm{IU} / \mathrm{ml}(55.21 \%)$, hepatitis $\mathrm{B}$ e antigen $\geq 2 \log 10 \mathrm{~S} / \mathrm{CO}(70.83 \%)$. Before treatment, there was no significant difference in hepatitis B virus-deoxyribonucleic acid load, hepatitis B surface antigen, hepatitis $B$ e antigen, serum alanine aminotransferase and aspartate aminotransferase levels between the telbivudine group and the entecavir group $(p>0.05)$, after $12 \mathrm{w}$ of treatment, the hepatitis $B$ virus-deoxyribonucleic acid load, hepatitis $B$ surface antigen, hepatitis $B$ e antigen, serum alanine aminotransferase and aspartate aminotransferase levels were not statistically significant $(p>0.05)$. The levels of hepatitis B virus-deoxyribonucleic acid load, hepatitis B surface antigen, hepatitis B e antigen, serum alanine aminotransferase and aspartate aminotransferase in the telbivudine group were lower than those in the entecavir group and the difference was statistically significant $(p<0.05)$. Before treatment, the interferon gamma and interleukin-2 levels of the telbivudine group and the entecavir group were compared with Interleukin-4, Interleukin-6 and regulatory $T$ cells/T helper 17 cells, the difference was not statistically significant ( $\mathbf{p}>\mathbf{0 . 0 5}$ ). After $12 \mathrm{w}$ of treatment, the levels of interferon gamma and interleukin-2 in the telbivudine group were higher than those in the entecavir group. The difference was statistically significant $(\mathbf{p}<\mathbf{0 . 0 5})$. The regulatory $T$ cells/ $T$ helper 17 cells of the telbivudine group was lower than that of the entecavir group and the difference was statistically significant $(p<0.05)$. The hepatitis $B$ surface antigen positive rate of newborns in the telbivudine group was lower than that of the entecavir group and the difference was statistically significant $(p<0.05)$, compared with the 1 min appearance, pulse, grimace, activity and respiration score and newborn weight of newborns in the Telbivudine and Entecavir groups, the difference was not statistically significant $(p>0.05)$. The main time for the onset of hepatitis in pregnant women with hepatitis $B$ virus infection is the second trimester. The liver function and hepatitis $B$ virusdeoxyribonucleic acid load of hepatitis $B$ virus infected pregnant women with hepatitis are more serious

*Address for correspondence

E-mail: bxl32298@163.com 
than those without hepatitis. The treatment of telbivudine group is better than the treatment of entecavir in the treatment of hepatitis. Women have more significant effects on immune regulation and have better effects on anti-virus and blocking mother-to-child transmission.

Key words: Chronic hepatitis B virus, hepatitis attack, telbivudine, entecavir, hepatitis b virusdeoxyribonucleic acid load

Chronic hepatitis B virus (HBV) infection is a global public health problem and China is the middle and high prevalence area of HBV infection. HBV can be transmitted through mother-to-child transmission, sexual transmission and blood transmission and motherto-child transmission is an important transmission route. How to block the mother-to-child transmission of $\mathrm{HBV}$ is the focus of current clinical research ${ }^{[1]}$. During pregnancy, maternal liver blood supply decreases and load metabolism increases. When the body has chronic HBV infection, it is not easy to lead to hepatitis during pregnancy. Severe cases can occur like liver failure, coagulation abnormalities and even lead to fetal intrauterine distress, premature delivery, stillbirth and other adverse pregnancy outcomes. Therefore, pregnant women with HBV infection should pay attention to monitoring liver function during pregnancy ${ }^{[2]}$.

Antiviral therapy for pregnant women with high viral load is helpful to block mother-to-child transmission of HBV. At present, antiviral drugs for clinical treatment of HBV infection include interferons and nucleoside (acid) analogues ${ }^{[3]}$. Entecavir and telbivudine are nucleoside analogues, which can reduce hepatitis $\mathrm{B}$ virus-deoxyribonucleic acid (HBV-DNA) load, inhibit HBV replication and improve hepatitis $\mathrm{B}$ e antigen $(\mathrm{HBeAg})$ seroconversion ${ }^{[4]}$. However, there are few studies on the difference in the efficacy of the two drugs in the hepatitis attack of pregnant women with HBV infection. This study was to investigate the clinical characteristics of hepatitis in pregnant women with HBV infection and the efficacy of telbivudine treatment.

\section{MATERIALS AND METHODS}

\section{Information}

In this study, 136 pregnant women with HBV infection diagnosed in our hospital from March 2017 to December 2018 were selected as subjects. According to whether patients had hepatitis attacks, they were divided into attack group (96 cases) and non-attack group (40 cases).

Inclusion criteria: Pregnant women with chronic HBV infection, HBV-DNA, HBeAg, hepatitis B surface antigen (HBsAg) were positive; patients aged 22-36 y; the diagnostic criteria of pregnancy complicated with hepatitis attack was HBV-DNA positive, the serum alanine aminotransferase (ALT) continued to rise and the upper limit of the normal value was 2 times higher; the research program was approved by the Medical Ethics Committee and the family members and their own informed consent were obtained before treatment.

Exclusion criteria: Patients with other types of viral hepatitis (type A, type $\mathrm{C}$, etc.); patients with immunodeficiency; tumor diseases; other types of virus or parasite infection (rubella, cytomegalovirus, toxoplasma, etc.); complicated with gestational diabetes mellitus, cholestasis of pregnancy, gestational hypertension and other diseases; congenital genetic defects, etc.

Attack group age range from 22-36 y old with average age of $27.6 \pm 3.0 \mathrm{y}$ old and non-attack group age range from $22-36$ y old with average age of $27.9 \pm 3.2$ y old and there was no significant difference in age between the two groups $(\mathrm{p}>0.05)$.

\section{Treatment methods}

The telbivudine group was given telbivudine tablets (Beijing Novartis Pharmaceutical Co., Ltd., specification: $600 \mathrm{mg}, \mathrm{H} 20070028)$ orally $600 \mathrm{mg} /$ time, once daily. Entecavir group was given oral administration of Entecavir dispersible tablets (Zhengda Tianqing Pharmaceutical Group Co., Ltd., specification: $0.5 \mathrm{mg}$, Chinese medicine Zhunzi H20100019) $0.5 \mathrm{mg} /$ time, once daily.

\section{Observation indicators and detection methods}

The changes of HBV-DNA load, HBsAg, HBeAg and ALT at different time points before and after treatment, the changes of peripheral blood $\mathrm{T}$ helper cell $(\mathrm{Th})$ factor interferon gamma (INF- $\gamma$ ), interleukin-2 (IL-2), interleukin-4 (IL-4), interleukin-6 (IL-6) and regulatory $\mathrm{T}$ cells/T helper 17 cells (Treg/Th17) and neonatal outcomes were compared.

Fasting venous blood samples were collected before treatment and $12 \mathrm{w}$ after treatment to detect HBV-DNA load, HBsAg, HBeAg, ALT, aspartate aminotransferase 
(AST), INF- $\gamma$, IL-2, IL-4, IL-6, Treg/Th17 and other indicators. Venous blood samples were centrifuged within $1 \mathrm{~h}$, centrifuged at $3500 \mathrm{rpm}$ for $10 \mathrm{~min}$. Reverse transcription-polymerase chain reaction (RT-PCR)was used to detectHBV-DNAload, polymerase chain reaction (PCR) quantitative analysis kit for Sun Yat-sen University Da An Gene Co., Ltd. HBsAg and $\mathrm{HBeAg}$ were detected by chemiluminescence immunoassay. ALT and AST were detected by international federation of clinical chemistry (IFCC) rate method, detection instrument: Beckman-Kurt AU680 automatic biochemical analyzer. INF- $\gamma$, IL-2, IL-4, IL-6 were detected by enzyme-linked immunosorbent assay (ELISA) Shenzhen Mairui Medical Electronics Co., Ltd. RT-96A enzyme labelling instrument, kit for Shenzhen Piji Bioengineering Company products. Another venous blood sample was taken and Treg/ Th17 was detected by flow cytometry. The detection instrument was CytoFLEX flow cytometer from Beckman-Kurt Company, USA.

\section{Statistical processing}

SPSS 21.0 was used for data processing software. In this study, the measurement indexes of INF- $\gamma$, IL2, IL-4, IL-6 and Treg/Th17 were tested by normal distribution, which were in line with approximate normal distribution or normal distribution. The data were expressed as $(\overline{\mathrm{x}} \pm \mathrm{s})$ and the data were compared by t test. $\chi^{2}$ test was used for comparison between groups of enumeration data, test level $\alpha=0.05$.

\section{RESULTS AND DISCUSSION}

The HBV-DNA load, HBsAg, HBeAg, ALT and AST levels in the hepatitis attack group were higher than those in the non-attack group and the differences were statistically significant $(\mathrm{p}<0.05)$ (Table 1$)$.

The age of patients in the hepatitis attack group was mainly concentrated in the range of 22-28 y old $(56.25 \%)$, the attack time was mainly concentrated in $13-24 \mathrm{w}(87.50 \%)$, the HBV-DNA level was mainly $\geq 6 \quad \log _{10} \mathrm{IU} / \mathrm{ml} \quad(78.13 \%), \quad \mathrm{HBsAg} \geq 4 \quad \log _{10} \mathrm{IU} / \mathrm{ml}$ $(55.21 \%)$ and $\mathrm{HBeAg} \geq 22 \log _{10} \mathrm{~S} / \mathrm{CO}(70.83 \%)$, Table 2.

There was no significant difference in age, gestational age, body mass index (BMI), gravidity, parity, HBVDNA load, HBsAg, HBeAg, ALT and AST between telbivudine group and entecavir group ( $\mathrm{p}>0.05)$, Table 3.

Before treatment, there was no significant difference in HBV-DNA load, HBsAg, HBeAg, ALT and AST levels between telbivudine group and entecavir group

TABLE 1: COMPARISON OF LIVER FUNCTION AND HBV INFECTION RELATED INDEXES BETWEEN HEPATITIS, ONSET GROUP AND NON-ONSET GROUP $(\overline{\mathbf{x}} \pm \mathbf{s})$

\begin{tabular}{lcccccc}
\hline Group & $\mathrm{n}$ & $\mathrm{ALT}(\mathrm{U} / \mathrm{L})$ & $\mathrm{AST}(\mathrm{U} / \mathrm{L})$ & $\mathrm{HBV}-\mathrm{DNA}\left(\log _{10} \mathrm{IU} / \mathrm{ml}\right)$ & $\mathrm{HBsAg}\left(\log _{10} \mathrm{IU} / \mathrm{ml}\right)$ & $\mathrm{HBeAg}\left(\log _{10} \mathrm{~S} / \mathrm{CO}\right)$ \\
\hline Seizure group & 96 & $185.0 \pm 41.7$ & $192.0 \pm 48.4$ & $7.41 \pm 1.18$ & $4.22 \pm 0.87$ & $2.84 \pm 0.66$ \\
Non-seizure group & 40 & $25.7 \pm 7.0$ & $28.0 \pm 8.5$ & $6.86 \pm 1.06$ & $3.78 \pm 0.74$ & $2.50 \pm 0.60$ \\
$\mathrm{t}$ & & 23.970 & 21.250 & 2.549 & 2.803 & 2.809 \\
$\mathrm{p}$ & 0.000 & 0.000 & 0.012 & 0.006 & 0.006 \\
\hline
\end{tabular}

TABLE 2: CLINICAL CHARACTERISTICS OF HEPATITIS ATTACK GROUP

\begin{tabular}{lcc}
\hline Project & Cases & $\begin{array}{c}\text { Composition } \\
\text { ratio (\%) }\end{array}$ \\
\hline Age $(\mathrm{y})$ & & \\
$22 \sim 28 \mathrm{y}$ & 54 & $56.25 \%$ \\
$29 \sim 35 \mathrm{y}$ & 42 & $43.75 \%$ \\
Hepatitis onset gestational (week) & & \\
$<12 \mathrm{w}$ & 12 & $12.50 \%$ \\
$13 \sim 24 \mathrm{w}$ & 84 & $87.50 \%$ \\
$\mathrm{HBV}-\mathrm{DNA}\left(\log _{10} \mathrm{IU} / \mathrm{ml}\right)$ & & \\
$<6$ & 21 & $21.88 \%$ \\
$\geq 6$ & 75 & $78.13 \%$ \\
$\mathrm{HBsAg}\left(\log _{10} \mathrm{IU} / \mathrm{ml}\right)$ & & \\
$<4$ & 43 & $44.79 \%$ \\
$\geq 4$ & 53 & $55.21 \%$ \\
$\mathrm{HBeAg}\left(\log _{10} \mathrm{~S} / \mathrm{CO}\right)$ & & \\
$<2$ & 28 & $29.17 \%$ \\
$\geq 2$ & 68 & $70.83 \%$ \\
\hline
\end{tabular}


( $>0.05)$. After $12 \mathrm{w}$ of treatment, the HBV-DNA load, ALT and AST levels telbivudine group were lower than those in entecavir group and the difference was statistically significant $(\mathrm{p}<0.05)$, Table 4 .

Before treatment, there were no significant differences in INF- $\gamma$, IL-2, IL-4, IL-6 and Treg/Th17 between telbivudine group and entecavir group $(\mathrm{p}>0.05)$. After $12 \mathrm{w}$ of treatment, the levels of INF- $\gamma$ and IL-2 in the telbivudine group were higher than those in the entecavir group and the difference was statistically significant $(\mathrm{p}<0.05)$. The Treg/Th17 in the telbivudine group was lower than that in the entecavir group and the difference was statistically significant ( $\mathrm{p}<0.05)$, Table 5 .

The positive rate of HBsAg in neonates in telbivudine group was lower than that in entecavir group and the difference was statistically significant $(\mathrm{p}<0.05)$. There was no statistically significant difference in appearance, pulse, grimace, activity and respiration (Apgar) score and neonatal weight at $1 \mathrm{~min}$ between telbivudine group and entecavir group ( $\mathrm{p}>0.05)$, Table 6 .

China is a high risk area of chronic hepatitis B, mother-to-child transmission is an important way to cause the accumulation of chronic hepatitis B cases. In addition, due to the special physiological period of pregnancy, the body metabolism is fast and the liver burden is increased. Therefore, pregnant women with HBV infection are prone to hepatitis attacks during pregnancy, resulting in significant damage to liver function, which can, not only cause protein synthesis disorders, hypoalbuminemia and anemia during pregnancy, increase the risk of infection, affect fetal growth and development but also cause abnormal coagulation function and increase the risk of bleeding during delivery ${ }^{[5]}$. In addition, severe liver damage can also cause the decrease of antidiuretic hormone, aldosterone and other inactivated ability, increase the

TABLE 3: COMPARISON OF GENERAL INFORMATION BETWEEN TELBIVUDINE GROUP AND ENTECAVIR GROUP ( $\overline{\mathbf{x}} \pm \mathbf{s})$

\begin{tabular}{lcccc}
\hline Normal information & Telbivudine group $(\mathbf{n}=48)$ & Entecavir group $(\mathbf{n}=48)$ & $\mathrm{t}$ & $\mathrm{p}$ \\
\hline Age $(\mathrm{y})$ & $27.8 \pm 2.8$ & $27.4 \pm 2.9$ & 0.687 & 0.493 \\
Onset of pregnancy (week) & $19.6 \pm 2.7$ & $20.0 \pm 3.0$ & -0.687 & 0.494 \\
BMl $\left(\mathrm{kg} / \mathrm{m}^{2}\right)$ & $25.8 \pm 2.3$ & $25.6 \pm 2.6$ & 0.399 & 0.691 \\
Pregnancy times (times) & $2.11 \pm 0.78$ & $2.32 \pm 0.94$ & -1.191 & 0.237 \\
Parity (times) & $0.83 \pm 0.27$ & $0.81 \pm 0.30$ & 0.343 & 0.732 \\
$\mathrm{HBV}-\mathrm{DNA}\left(\log _{10} \mathrm{IU} / \mathrm{ml}\right)$ & $7.45 \pm 1.12$ & $7.37 \pm 1.04$ & 0.363 & 0.718 \\
$\mathrm{HBsAg}\left(\log _{10} \mathrm{lU} / \mathrm{ml}\right)$ & $4.28 \pm 0.81$ & $4.16 \pm 0.85$ & 0.708 & 0.481 \\
$\mathrm{HBeAg}\left(\log _{10} \mathrm{~S} / \mathrm{CO}\right)$ & $2.90 \pm 0.62$ & $2.78 \pm 0.64$ & 0.933 & 0.353 \\
ALT $(\mathrm{U} / \mathrm{L})$ & $188.3 \pm 39.5$ & $181.7 \pm 40.8$ & 0.805 & 0.423 \\
AST (U/L) & $189.5 \pm 46.6$ & $194.5 \pm 43.7$ & -0.542 & 0.589
\end{tabular}

TABLE 4: COMPARISON OF ANTIVIRAL TREATMENT EFFECTS BETWEEN TELBIVUDINE GROUP AND ENTECAVIR GROUP $(\overline{\mathbf{x}} \pm \mathbf{s})$

\begin{tabular}{|c|c|c|c|c|c|c|c|c|}
\hline \multirow[b]{2}{*}{ Index } & \multicolumn{2}{|c|}{ Before therapy } & \multirow[b]{2}{*}{$t$} & \multirow[b]{2}{*}{ p } & \multicolumn{2}{|c|}{ After $12 \mathrm{w}$ of treatment } & \multirow[b]{2}{*}{$\mathrm{t}$} & \multirow[b]{2}{*}{$\mathbf{p}$} \\
\hline & $\begin{array}{l}\text { Telbivudine } \\
\text { group }(n=48)\end{array}$ & $\begin{array}{l}\text { Entecavir group } \\
(\mathrm{n}=48)\end{array}$ & & & $\begin{array}{l}\text { Telbivudine } \\
\text { group }(n=48)\end{array}$ & $\begin{array}{c}\text { Entecavir } \\
\text { group }(n=48)\end{array}$ & & \\
\hline HBV-DNA $\left(\log _{10} \mathrm{IU} / \mathrm{ml}\right)$ & $7.45 \pm 1.12$ & $7.37 \pm 1.04$ & 0.363 & 0.718 & $3.10 \pm 0.84^{*}$ & $3.58 \pm 0.92^{*}$ & -2.669 & 0.009 \\
\hline $\mathrm{HBsAg}\left(\log _{10} \mathrm{IU} / \mathrm{ml}\right)$ & $4.28 \pm 0.81$ & $4.16 \pm 0.85$ & 0.708 & 0.481 & $1.45 \pm 0.56^{*}$ & $1.61 \pm 0.62^{*}$ & -1.327 & 0.188 \\
\hline $\mathrm{HBeAg}\left(\log _{10} \mathrm{~S} / \mathrm{CO}\right)$ & $2.90 \pm 0.62$ & $2.78 \pm 0.64$ & 0.933 & 0.353 & $0.87 \pm 0.29^{*}$ & $0.94 \pm 0.31^{*}$ & -1.142 & 0.256 \\
\hline $\operatorname{ALT}(\mathrm{U} / \mathrm{L})$ & $188.3 \pm 39.5$ & $181.7 \pm 40.8$ & 0.805 & 0.423 & $48.9 \pm 12.6^{*}$ & $59.2 \pm 15.2^{*}$ & -3.614 & 0.000 \\
\hline AST (U/L) & $189.5 \pm 46.6$ & $194.5 \pm 43.7$ & -0.542 & 0.589 & $53.2 \pm 14.5^{*}$ & $62.8 \pm 16.0^{*}$ & -3.080 & 0.003 \\
\hline
\end{tabular}

TABLE 5: COMPARISON OF T CELL FACTORS AND TREG/TH17 VALUES BETWEEN TELBIVUDINE GROUP AND ENTECAVIR GROUP

\begin{tabular}{|c|c|c|c|c|c|c|c|c|}
\hline \multirow[b]{2}{*}{ Index } & \multicolumn{2}{|c|}{ Before therapy } & \multirow[b]{2}{*}{$\mathrm{t}$} & \multirow[b]{2}{*}{$\mathrm{p}$} & \multicolumn{2}{|c|}{ After $12 \mathrm{w}$ of treatment } & \multirow[b]{2}{*}{$\mathrm{t}$} & \multirow[b]{2}{*}{$\mathrm{p}$} \\
\hline & $\begin{array}{c}\text { Telbivudine } \\
\text { group }(n=48)\end{array}$ & $\begin{array}{l}\text { Entecavir group } \\
(\mathrm{n}=48)\end{array}$ & & & $\begin{array}{l}\text { Telbivudine group } \\
(\mathrm{n}=48)\end{array}$ & $\begin{array}{l}\text { Entecavir group } \\
(n=48)\end{array}$ & & \\
\hline INF- $\gamma(\mathrm{pg} / \mathrm{ml})$ & $153.2 \pm 16.4$ & $150.5 \pm 17.0$ & 0.792 & 0.430 & $186.2 \pm 18.4^{*}$ & $176.4 \pm 17.8^{*}$ & 2.652 & 0.009 \\
\hline IL-2 (pg/ml) & $14.30 \pm 3.76$ & $14.73 \pm 3.41$ & -0.587 & 0.559 & $22.59 \pm 5.10^{*}$ & $19.56 \pm 5.57^{*}$ & 2.780 & 0.007 \\
\hline $\mathrm{IL}-4(\mathrm{pg} / \mathrm{ml})$ & $10.64 \pm 2.74$ & $10.15 \pm 2.86$ & 0.857 & 0.394 & $5.51 \pm 1.83^{*}$ & $6.02 \pm 1.90^{*}$ & -1.339 & 0.184 \\
\hline IL-6 (pg/ml) & $17.68 \pm 4.19$ & $16.94 \pm 4.42$ & 0.842 & 0.402 & $8.52 \pm 2.50^{*}$ & $9.13 \pm 2.83^{*}$ & -1.119 & 0.266 \\
\hline Treg/Th17 & $3.10 \pm 0.61$ & $2.95 \pm 0.66$ & 1.156 & 0.250 & $1.58 \pm 0.49^{*}$ & $1.84 \pm 0.55^{*}$ & -2.445 & 0.016 \\
\hline
\end{tabular}

Note: Compared with this group before treatment ${ }^{*} \mathrm{p}<0.05$ 
TABLE 6: NEWBORNS IN TELBIVUDINE GROUP AND ENTECAVIR GROUP

\begin{tabular}{|c|c|c|c|c|c|}
\hline \multirow{2}{*}{ Group } & \multirow[b]{2}{*}{$\mathbf{n}$} & \multicolumn{2}{|c|}{ Newborn HBsAg (\%) } & \multirow{2}{*}{1 min Apgar scores } & \multirow{2}{*}{ Newborn weight (g) } \\
\hline & & Positive & Negative & & \\
\hline Telbivudine group & 48 & $0(0.00)$ & $48(100.00)$ & $8.84 \pm 0.38$ & $2914.5 \pm 114.0$ \\
\hline Entecavir group & 48 & $4(8.33)$ & $44(91.67)$ & $8.72 \pm 0.40$ & $2886.3 \pm 98.6$ \\
\hline$t / x^{2}$ & & \multicolumn{2}{|c|}{4.174} & 1.507 & 1.296 \\
\hline $\mathrm{p}$ & & \multicolumn{2}{|c|}{0.041} & 0.135 & 0.198 \\
\hline
\end{tabular}

risk of gestational hypertension and abnormal glucose metabolism ${ }^{[6]}$.

In this study, liver function related indicators were monitored during pregnancy and it was found that the HBV-DNA load, HBsAg, HBeAg, ALT and AST levels of hepatitis authors in pregnant women with HBV infection were higher than those of non-hepatitis authors in pregnant women with HBV infection. It suggested that the hepatitis attack of $\mathrm{HBV}$-infected pregnant women was mainly in the middle of pregnancy. The liver function damage and HBV-DNA load of HBVinfected pregnant women with hepatitis attack were more serious than those of patients without hepatitis attack and HBV replication activity was stronger. The general data of patients were compared and it was found that the age of hepatitis authors in pregnant women with HBV infection was mainly concentrated in the range of 22-28 y old and the attack time was mainly concentrated in 13-24 w. The levels of HBVDNA were mainly $\geq 6 \log _{10} \mathrm{IU} / \mathrm{ml}, \mathrm{HBsAg} \geq 4 \log _{10} \mathrm{IU} /$ $\mathrm{ml}, \mathrm{HBe} A g \geq 2 \log _{10} \mathrm{~S} / \mathrm{CO}$. In the future clinical work, liver function monitoring should be carried out during pregnancy in order to timely detect hepatitis attacks in pregnant women with HBV infection and give timely treatment.

Telbivudine and entecavir are commonly used nucleoside antiviral drugs in clinic. Liao Jinyao ${ }^{[7]}$ and other studies believe that the effect of telbivudine and entecavir in the treatment of HBV infection is similar and the early anti-HBV effect of telbivudine is better than that of entecavir. Lin et al ${ }^{[8]}$ found that the clinical response rate of telbivudine in the treatment of chronic hepatitis B was higher than that of entecavir, which may be related to the regulation of High mobility group box 1 (HMGB-1), IFN- $\gamma$, IL-4, IL-10 and other cytokines. However, there are few comparative studies on the application of these two drugs in patients with HBV infection during pregnancy. In this study, telbivudine and entecavir were used to treat hepatitis attack in pregnant women with HBV infection. After $12 \mathrm{w}$ of treatment, HBV-DNA load, ALT and AST levels in patients treated with telbivudine were lower than those in patients treated with entecavir. This result suggests that telbivudine treatment has better antiviral and liver function protection effects than entecavir treatment in pregnant women with hepatitis. This is because telbivudine can compete with 5-triphosphate of HBVDNA to inhibit HBV-DNA activity, thereby inhibiting HBV replication in vivo and reducing its damage to liver cells ${ }^{[9]}$.

Some studies suggest that patients with HBV infection are mostly in immune disorder. Treg cells participate in the immune pathogenesis of HBV infection and maintain the immune tolerance of the body together with $\mathrm{HBeAg}{ }^{[10-12]}$. Th17 cells are involved in HBV-specific immune response and cause liver immune damage. Treg/Th17 can reflect the state of immune function ${ }^{[13,14]}$. In this study, the levels of Th cytokines INF- $\gamma$, IL-2, IL4, IL-6 and Treg/Th17 ratio were detected. It was found that telbivudine treatment had more significant effect on immune regulation than entecavir in the treatment of hepatitis in pregnant women with HBV infection, which was one of the mechanisms of better therapeutic effect.

At present, hepatitis B immunoglobulin combined with hepatitis B vaccine has been widely used for neonatal immunization in clinic, which can reduce the risk of mother-to-child transmission of pregnant women with HBV infection, but there are still $5 \%-15 \%$ prevention failures ${ }^{[15]}$. This study found that telbivudine can better reduce the positive rate of neonatal $\mathrm{HBsAg}$ and does not affect the neonatal 1 min Apgar score and neonatal weight, suggesting that telbivudine has good efficacy and safety as antiviral and blocking mother-to-child transmission drugs.

In summary, the main time of hepatitis attack in pregnant women with HBV infection is in the middle of pregnancy. The liver function damage and HBV-DNA load of HBV-infected pregnant women with hepatitis attack were more serious than those of patients without hepatitis attack. The effect of telbivudine on immune regulation was more significant than that of entecavir in the treatment of hepatitis attack pregnant women and the effect of antiviral and blocking mother-to-child transmission was better. 


\section{Conflicts of Interest:}

The authors declared no conflict of interest.

\section{REFERENCES}

1. Terrault NA, Lok AS, McMahon BJ, Chang KM, Hwang JP, Jonas MM, et al. Update on prevention, diagnosis and treatment of chronic hepatitis B: AASLD 2018 hepatitis B guidance. Hepatology 2018;67(4):1560-99.

2. Kayaaslan B, Akinci E, Ari A, Tufan ZK, Alpat SN, Gunal O, et al. A long-term multicenter study: Entecavir versus Tenofovir in treatment of nucleos $(\mathrm{t})$ ide analogue-naive chronic hepatitis B patients. Clin Res Hepatol Gastroenterol 2018;42(1):40-7.

3. Cryer AM, Imperial JC. Hepatitis B in pregnant women and their infants. Clin Liver Dis 2019;23(3):451-62.

4. Owens DK, Davidson KW, Krist AH, Barry MJ, Cabana $\mathrm{M}$, Caughey $\mathrm{AB}$, et al. Screening for hepatitis $\mathrm{B}$ virus infection in pregnant women: US preventive services task force reaffirmation recommendation statement. JAMA 2019;322(4):349-54

5. Seo KI, Bae SH, Sung PS, Park CH, Lee HL, Kim HY, et al. Effect of antiviral therapy in reducing perinatal transmission of hepatitis B virus and maternal outcomes after discontinuing them. Clin Mol Hepatol 2018;24(4):374-83.

6. Thilakanathan C, Wark G, Maley M, Davison S, Lawler $\mathrm{J}$, Lee A, et al. Mother-to-child transmission of hepatitis B: Examining viral cut-offs, maternal HBsAg serology and infant testing. Liver Int 2018;38(7):1212-9.

7. Liao JY, Xiao Y, Huang J, Chen WL, Chen R. Effects of telbivudine and entecavir in the treatment of patients with hepatitis B virus infections. Chin J nosocomial 2018;28(7):9836.

8. Lin Y, Sun Y. Entecavir and telbivudine clinical observation of treating chronic hepatitis B. China Med Guide 2019;16(15):104-7.
9. Thilakanathan C, Wark G, Maley M, Davison S, Lawler $\mathrm{J}$, Lee A, et al. Mother-to-child transmission of hepatitis B: Examining viral cut-offs, maternal HBsAg serology and infant testing. Liver Int 2018;38(7):1212-9.

10. Basha A, Amarin Z, Haloub K, Kharabsheh A, Qudah O, AbuKhader I. Epidemiology of hepatitis B and $\mathrm{C}$ in a pregnant woman in a tertiary teaching hospital in Jordan. Clin Exp Obstet Gynecol 2019;46(5):723-6.

11. Gatheru Z, Murila F, Mbuthia J, Okoth F, Kanyingi F, Mugo $\mathrm{F}$, et al. Factors associated with hepatitis B surface antigen seroprevalence amongst pregnant women in Kenya. Open $\mathrm{J}$ Obstet Gynecol 2018;8(05):456-7.

12. Farsimadan M, Motamedifar M. The effects of human immunodeficiency virus, human papillomavirus, herpes simplex virus-1 and 2, human herpesvirus-6 and 8, cytomegalovirus and hepatitis $\mathrm{B}$ and $\mathrm{C}$ virus on female fertility and pregnancy. Br J Biomed Sci 2021;78(1):1-11.

13. Elsharkawy SS, Elgazayerli WS. Sero-Prevalence of HBV, $\mathrm{HCV}$ and HEV among the Egyptian Pregnant Females. Open J Obstet Gynecol 2019;9(10):1429-38.

14. Calix RX, Loeliger KB, Burn MS, Campbell KH. Acute herpes simplex virus hepatitis in pregnancy. Obstet Gynecol 2020;135(2):396-400.

15. Badfar G, Shohani M, Nasirkandy MP, Mansouri A, Abangah $\mathrm{G}$, Rahmati S, et al. Epidemiology of hepatitis B in pregnant Iranian women: a systematic review and meta-analysis. Arch Virol 2018;163(2):319-30.

This is an open access article distributed under the terms of the Creative Commons Attribution-NonCommercial-ShareAlike 3.0 License, which allows others to remix, tweak, and build upon the work non-commercially, as long as the author is credited and the new creations are licensed under the identical terms

This article was originally published in a special issue, "Evolutionary Strategies in Biomedical Research and Pharmaceutical Sciences" Indian J Pharm Sci 2021:83(3) Spl issue; $180-185$ 